\title{
Arbeidstevredenheid: gevolg van werkkenmerken, werkwaarden of beide?
}

\author{
Marije Evers, Jan Fekke Ybema, Peter Smulders*
}

In een steekproef van de Nederlandse beroepsbevolking ( $N=4009$ ) is bekeken hoe werkkenmerken en werkwaarden samenhangen met de tevredenheid met het werk. In overeenstemming met het Vitaminemodel werd verwacht dat de aanwezigheid van een werkkenmerk alleen onder bepaalde omstandigheden tot (meer) tevredenheid leidt. In dit onderzoek werd verondersteld dat een werkkenmerk vooral tot meer arbeidstevredenheid leidt wanneer er een goede fit is tussen werkwaarde en werkkenmerk. Sommige onderzoeken laten zien dat een goede fit een positief effect heeft op de arbeidstevredenheid, terwijl andere onderzoeken hier weinig of geen steun voor vinden. Uit de resultaten bleek dat in drie van de zeven gevallen een goede fit tussen werkwaarde en werkkenmerk bijdroeg aan een grotere arbeidstevredenheid. Naast de kenmerken van het werk is dus ook de mate waarin werkwaarden en werkkenmerken bij elkaar passen belangrijk voor de arbeidstevredenheid.

Trefwoorden: werkwaarden, taalkenmerken, arbeidssatisfactie

\section{Inleiding}

Arbeidstevredenheid kan gezien worden als de mate waarin werkenden hun werk plezierig vinden (Agho, Mueller \& Price, 1993). Het is een attitude die gebaseerd is op de positieve en negatieve percepties van het werk en de werkomgeving (Pool, 1997). Een grote mate van arbeidstevredenheid is positief voor de werknemer zelf, maar ook voor de werkgever. Arbeidstevredenheid draagt namelijk bij aan psychisch

\footnotetext{
* Marije Evers is werkzaam als onderzoeker bij TNO Kwaliteit van Leven. Correspondentieadres: M.S. Evers, TNO Kwaliteit van Leven/Arbeid, Postbus 718, 2130 AS Hoofddorp. E-mail: M.Evers@arbeid.tno.nl, telefoon: + 31 (023) 5549981, fax: + 31 (023) 5549304. Jan Fekke Ybema is werkzaam als onderzoeker bij TNO Kwaliteit van Leven. Peter Smulders is werkzaam als onderzoeker bij TNO Kwaliteit van Leven.
} 
welbevinden van de werkende, betrokkenheid bij het werk, een lagere verloopintentie, minder verzuim en in hogere functies zelfs aan een grotere productiviteit (Van Yperen \& De Jong, I997).

Arbeidstevredenheid wordt door verschillende factoren bepaald. In de eerste plaats door de kenmerken van het werk zelf (Achterberg, Houtman \& Jetten, 2003). Daarnaast is de mate waarin mensen tevreden zijn met hun werk ook afhankelijk van de waarde die zij aan bepaalde werkkenmerken hechten (Knoop, 1994). Idealiter sluit het werk dat mensen doen aan bij de werkwaarden die zij hebben. In dit artikel onderzoeken we of een goede afstemming tussen werkwaarden en werkkenmerken bijdraagt aan de arbeidstevredenheid. Het artikel beoogt bij te dragen aan de kennis over arbeidstevredenheid. De verklaring van arbeidstevredenheid geeft werkgevers en werknemers handvatten om de arbeidstevredenheid te vergroten met positieve resultaten voor beide partijen tot gevolg.

\subsection{Werkkenmerken}

Verschillende theorieën brengen kenmerken van het werk in verband met uitkomsten van het werk zoals productiviteit, arbeidsmotivatie of arbeidstevredenheid. Het Vitaminemodel van Warr (1987) stelt dat omgevingskenmerken, zoals werkkenmerken, een vergelijkbaar effect hebben op de mentale gezondheid als vitamines op de fysieke gezondheid. Het binnenkrijgen van vitamines is gezond, maar na een bepaald niveau stopt het positieve effect (vitamines $\mathrm{C}$ en $\mathrm{E}$ ) en kan dit zelfs omslaan in een negatief effect (A en D) op de gezondheid. Het Vitaminemodel voorspelt dat analoog aan de werking van de vitamines $\mathrm{A}$ en $\mathrm{D}$, autonomie tot meer arbeidstevredenheid leidt, maar dat de arbeidstevredenheid weer afneemt als er een overdosis ontstaat. Meer autonomie leidt volgens Warr (1987) dus niet altijd tot meer arbeidstevredenheid. Ook voor de werkkenmerken taakeisen, sociale steun, gebruiken van vaardigheden, variëteit in vaardigheden en feedback op taken geldt volgens het Vitaminemodel dat een overdosis van deze werkkenmerken tot een lagere arbeidstevredenheid leidt. Een teveel aan taakeisen kan bijvoorbeeld leiden tot burnoutklachten (Peeters \& Le Blanc, 200I) en teveel sociale steun kan een bedreiging van de eigenwaarde vormen (Nadler, I99I). Andere werkkenmerken, zoals het maandinkomen, de veiligheid en het belang van de taak, hebben eenzelfde werking als de vitamines $\mathrm{C}$ en $\mathrm{E}$. Een hoger inkomen, meer veiligheid en een groter belang van de taak leiden, boven een bepaalde waarde, niet tot meer arbeidstevredenheid, maar verlagen de arbeidstevredenheid ook niet. Het Vitaminemodel onderscheidt naast de verschillende typen werkkenmerken vier categorieën van persoonskenmerken: demografische kenmerken, vaardigheden, waarden en fundamentele mentale gezondheid. Deze persoonskenmerken kunnen volgens het Vitaminemodel de relatie tussen de omgevingskenmerken en de mentale gezondheid beïnvloeden. Ten eerste kunnen de persoonskenmerken van invloed zijn op de omgevingskenmerken. Deze invloed kan gewild of ongewild zijn. Mensen met een lage sociaal-economische status komen bijvoorbeeld eerder in een baan terecht met weinig autonomie dan mensen met een hoge sociaal-economische status. Er kan ook sprake zijn van zelfselectie: werknemers met bepaalde werkwaarden zullen vooral werk zoeken dat bij hun waarden past. Ten tweede kunnen de persoonskenmerken van invloed zijn op de relatie tussen de omgevingskenmerken en de mentale gezondheid. Mensen met een 
grote behoefte aan een bepaald omgevingskenmerk zullen het betreffende kenmerk meer waarderen, wat resulteert in een betere mentale gezondheid. Wanneer het omgevingskenmerk afwezig is zal dit bij de mensen met een grote behoefte aan het kenmerk een sterker negatief effect hebben op de mentale gezondheid dan bij mensen met weinig behoefte aan het omgevingskenmerk (Warr, 1987). Toegespitst op dit artikel betekent dit dat de werkwaarden van een persoon van invloed kunnen zijn op de mate waarin werkkenmerken leiden tot arbeidstevredenheid. De kern van het Vitaminemodel is dat er een zeker optimum is voor werkkenmerken. Bij overschrijding van dat optimum kan de tevredenheid gelijk blijven of afnemen. In het algemeen is er echter weinig empirische steun gevonden voor de curvilineaire verbanden tussen AD-werkkenmerken en arbeidstevredenheid die het Vitaminemodel voorspelt (Jeurissen \& Nyklíček, 200r; De Jonge \& Schaufeli, I998).

In dit artikel sluiten we aan bij de redenering van het Vitamine model dat de aanwezigheid van een werkkenmerk alleen onder bepaalde omstandigheden tot (meer) tevredenheid leidt. We zoomen daarbij in op de modererende effecten van de werkwaarden op de relatie tussen werkkenmerken en arbeidstevredenheid. We verwachten dat de werkkenmerken vooral een positief effect hebben op de arbeidstevredenheid, wanneer mensen waarde hechten aan deze werkkenmerken. De werkkenmerken die we in dit artikel behandelen zijn autonomie, variatie in het werk, complex werk, steun van collega's, steun van de leidinggevende, baanzekerheid en maandinkomen. Bij de selectie van de werkkenmerken sluiten we zo veel mogelijk aan bij de werkkenmerken die het Vitamine model bespreekt.

\subsection{Werkwaarden}

Werkwaarden kunnen op verschillende manieren gedefinieerd worden. Zo worden werkwaarden gezien als een verzameling van attitudes en meningen waarmee mensen hun werk en werkomgeving evalueren, als een afspiegeling van motivationele aspecten, of als representatie van de Protestantse Werk Ethiek (Elizur, I996). In dit onderzoek beschrijven de werkwaarden de mate waarin mensen bepaalde werkkenmerken belangrijk vinden. Inmiddels is er heel wat onderzoek gedaan naar wat mensen belangrijk vinden in het werk. Twee langlopende internationale onderzoeken zijn het Meaning of Work (MOW) project (Harpaz, 2002; Van Hoof, Bruin, Schoemaker \& Vroom, 2002; Snir \& Harpaz, 2002) en de European Value Study (EVS) (Van Hoof et al., 2002). Daarnaast is er ook onderzoek op nationaal niveau (Ybema \& Smulders, 2004). De verschillende onderzoeken hebben niet naar dezelfde set werkwaarden gevraagd, wat vergelijking moeilijk maakt. Voorzichtig kan geconcludeerd worden dat interessant werk, passend werk, een goede beloning en goede collega's in Nederland tot de belangrijkste werkwaarden horen.

De werkwaarden zijn onder te verdelen in intrinsieke en extrinsieke factoren (Van Hoof, 2002; Snir \& Harpaz, 2002). Hechten aan het hebben van interessant werk, zelfstandig of gevarieerd werk, zijn intrinsieke werkwaarden: het gaat om de inhoud van het werk. Hechten aan een goede beloning en baanzekerheid zijn extrinsieke werkwaarden. Extrinsieke werkwaarden zijn werkwaarden die geen betrekking hebben op de inhoud van het werk. Het doel van het werk ligt buiten het werk zelf. Vooral intrinsieke werkwaarden worden in verband gebracht met positieve opbrengsten. Van der Velde, Feij en Van Emmerik (1998) stellen dat mensen met 
hoge intrinsieke werkwaarden meer tevreden zijn met het werk, meer carrière maken, meer streven naar opleiding, minder werkloos zijn, minder van baan veranderen, meer betrokken zijn bij de organisatie en hun werk meer trachten te vernieuwen dan mensen met lage intrinsieke werkwaarden. Knoop (1994) vond dat van 2I intrinsieke en extrinsieke werkwaarden vooral intrinsieke werkwaarden van belang zijn voor de arbeidstevredenheid. De werkwaarden die we in dit onderzoek bekijken zijn: belang van interessant werk, zelfstandigheid, variatie in het werk, goede beloning, goede baanzekerheid, goede collega's en goede leiding.

\subsection{Belang van een goede fit tussen werkwaarden en werkkenmerken}

Uit het voorgaande blijkt dat zowel het belang dat men hecht aan bepaalde aspecten van het werk als de kenmerken van het werk dat men doet, van invloed zijn op de arbeidstevredenheid. Idealiter sluit het werk aan bij wat men belangrijk vindt in het werk. Wanneer er een goede fit is tussen iemands werkwaarden en het werk dat diegene heeft, is er een grotere mate van tevredenheid te verwachten. Norris (2003) definieert arbeidstevredenheid zelfs als 'een relatief concept dat de overeenkomst weergeeft in eerdere bestaande motivationele waarden en latere werkervaringen'.

Het Vitaminemodel beschrijft dat mensen die belang hechten aan een bepaald werkkenmerk, bij de aanwezigheid van het werkkenmerk meer positieve gevolgen ervaren en bij afwezigheid meer negatieve gevolgen dan mensen die het betreffende werkkenmerk niet waarderen. Bij passende combinaties van persoons- en werkkenmerk is het interactie-effect van werkwaarde en werkkenmerk op de tevredenheid dus groter dan bij niet-passende combinaties (Boer, De Jonge \& Hamers, 2003). Voor CE-werkkenmerken geldt dat een misfit tussen werkwaarde en werkkenmerk met name tot minder tevredenheid leidt wanneer het werkkenmerk in geringe mate aanwezig is. Mensen met een lage behoefte aan een CE-werkkenmerk, zoals inkomen, zullen wanneer het inkomen hoog is wel iets minder tevreden zijn dan mensen met een grote behoefte aan een goed inkomen, maar het verschil zal gering zijn. Een misfit tussen AD-werkkenmerk en werkwaarde leidt bij zowel een geringe aanwezigheid als een sterke aanwezigheid van het werkkenmerk tot aanzienlijk minder tevredenheid in vergelijking met de situatie waarin er wel sprake is van een goede fit. Wanneer het AD-werkkenmerk in geringe mate aanwezig is, terwijl een persoon sterk hecht aan het werkkenmerk, zal de tevredenheid lager zijn dan wanneer de waarde die aan het werkkenmerk wordt gehecht klein is. Nadat het optimum voor het $\mathrm{AD}$-werkkenmerk bereikt is, neemt de tevredenheid voor mensen met een lage behoefte aan het werkkenmerk sterker af dan voor mensen met een grote behoefte aan het werkkenmerk (Warr, 1987).

Warr (I987) beschrijft een aantal combinaties van persoons- en werkkenmerken die zouden leiden tot meer tevredenheid. In tabel I presenteren we Warr's combinaties die dicht tegen de combinaties uit deze studie aanliggen. Met de werkwaarde 'growthneed strength' bedoelt Warr in welke mate iemand behoefte heeft aan autonomie, onafhankelijkheid en het leveren van prestaties. De tabel laat zien dat reeds in 1987 voor een aantal combinaties empirische steun was gevonden. Voor de andere combinaties geldt dat er weinig of geen empirische steun was gevonden, of dat er nog geen onderzoek naar was gedaan. 
Tabel 1 Combinaties van werkkenmerken en werkwaarden zoals beschreven door Warr (1987) en zoals gebruikt in deze studie

\begin{tabular}{llll}
$\begin{array}{l}\text { Werkkenmerk } \\
\text { Warr }\end{array}$ & $\begin{array}{l}\text { Bijpassende } \\
\text { werkwaarde Warr }\end{array}$ & $\begin{array}{l}\text { Werkkenmerk } \\
\text { in deze studie }\end{array}$ & $\begin{array}{l}\text { Bijpassende werkwaarde } \\
\text { in deze studie }\end{array}$ \\
\hline Autonomie & $\begin{array}{l}\text { Belang growth-need strength* Autonomie } \\
\text { Belang onafhankelijkheid* }\end{array}$ & $\begin{array}{l}\text { Belang zelfstandigheid in } \\
\text { het werk }\end{array}$ \\
\hline Variatie & $\begin{array}{l}\text { Belang growth-need strength* } \\
\text { Belang variatie* }\end{array}$ & Variatie & Belang variatie in het werk \\
\hline $\begin{array}{l}\text { Taakeisen } \\
\text { Mogelijkheid }\end{array}$ & Belang growth-need strength* & Complex werk & Belang interessant werk \\
$\begin{array}{l}\text { voor contact } \\
\text { met anderen }\end{array}$ & & Steun collega's & Belang goede collega's \\
\hline $\begin{array}{l}\text { Mogelijkheid } \\
\text { voor contact } \\
\text { met anderen }\end{array}$ & Belang sociale steun & Steun & Belang goede leiding \\
\hline Fysieke zekerheid & Belang fysieke zekerheid & Baanzekerheid & Belang zekerheid \\
\hline $\begin{array}{l}\text { Beschikbaarheid } \\
\text { van geld }\end{array}$ & Belang geld & Inkomen & Belang inkomen \\
\hline
\end{tabular}

* Fit tussen werkkenmerk en werkwaarde draagt significant bij aan arbeidstevredenheid (Warr, 1987).

Ook in de meer recente literatuur zijn aanwijzingen dat een goede fit tussen werkwaarden en werkkenmerken inderdaad leidt tot meer arbeidstevredenheid (Boer et al., 2003). Er zijn echter eveneens onderzoekers die niet, of slechts in beperkte mate, hebben gevonden dat een goede fit bijdraagt aan meer arbeidstevredenheid (Achterberg et al., 2003; Zurriaga, Ramos, Gonzalez-Roma, Espejo \& Zornoza, 2000).

Boer et al. (2003) hebben in hun onderzoek gekeken naar de relatie tussen de werkkenmerken autonomie en afwisseling en de werkwaarden behoefte aan opleiding en behoefte aan autonomie. De auteurs vonden dat autonomie en afwisseling in het werk niet voor iedereen een positief effect heeft op de arbeidstevredenheid. Zo toonden zij aan dat de behoefte aan autonomie een modererend effect heeft op de relatie tussen autonomie in het werk en arbeidstevredenheid. Voor mensen met behoefte aan autonomie, heeft autonomie in het werk een positief effect op tevredenheid. Voor mensen die geen behoefte hebben aan autonomie, heeft autonomie in het werk juist een negatieve invloed op arbeidstevredenheid. Dit onderzoek ondersteunt het idee dat een goede fit tussen werkwaarden en werkkenmerken tot meer tevredenheid leidt. Achterberg et al. (2003) hebben daarentegen slechts in beperkte mate steun gevonden voor dit idee. In twee van de acht gevallen leidde voor werknemers die al langere tijd hun functie bekleedden een goede fit tussen werkwaarden en werkkenmerken tot meer arbeidstevredenheid. Een betere fit tussen belang hechten aan autonomie en autonomie in het werk leidde tot meer arbeidstevredenheid. Ook een goede fit tussen belang hechten aan ontplooiingsmogelijkheden en het hebben van ontplooiingsmogelijkheden in het werk, leidde tot meer arbeidstevredenheid. Een goede fit tussen werkwaarde en werkkenmerk voor wat betreft de mogelijkheid voor sociale erkenning, 
de mogelijkheid voor sociale contacten, fysieke arbeidsomstandigheden, promotiekansen, netto-inkomen en baanzekerheid leidde niet tot meer arbeidstevredenheid. Aangezien de meeste combinaties van werkwaarde en werkkenmerk niet tot meer arbeidstevredenheid leidden, concludeerden de onderzoekers dat een goede fit tussen werkwaarden en werkkenmerken niet leidt tot een betere verklaring van arbeidstevredenheid. De onderzoekers kwamen tot de conclusie dat arbeidstevredenheid vooral wordt beïnvloed door de kenmerken van het werk zelf en niet door een fit tussen werkkenmerken en het belang dat aan die kenmerken gehecht wordt.

In deze studie gaan we na in welke mate een goede fit tussen werkwaarden en werkkenmerken samenhangt met de arbeidstevredenheid. Uit het voorafgaande leiden we af dat een fit tussen werkwaarde en werkkenmerk positief kan bijdragen aan de arbeidstevredenheid. Op basis van de eerder beschreven theorie en de besproken literatuur, verwachten we dat:

421 de werkkenmerken autonomie, variatie in het werk, complex werk, sociale steun van collega's en leidinggevende, baanzekerheid en inkomen positief samenhangen met arbeidstevredenheid;

2 werkwaarden die positief samenhangen met arbeidstevredenheid intrinsiek van aard zijn;

3 een goede fit tussen werkwaarde en werkkenmerk bijdraagt, na correctie voor het werkkenmerk en de werkwaarde afzonderlijk, aan meer arbeidstevredenheid.

\section{Methode van onderzoek}

\subsection{Onderzoeksdesign en -populatie}

De TNO Arbeidssituatie Survey (TAS) is een schriftelijke cross-sectionele survey die iedere twee jaar de arbeidssituatie in een random steekproef van de Nederlandse beroepsbevolking meet (Smulders, Andries \& Otten, 20or; Smulders \& Houtman, 2004). In 2002 is een aanvullende steekproeftrekking gedaan onder vrouwen en jongeren, omdat deze groepen ondervertegenwoordigd waren. In 2002 was de totale respons $45 \%$. De nettosteekproef van 4009 personen bestond uit $62 \%$ mannen en $38 \%$ vrouwen. De leeftijd varieerde van I $_{5}$ tot en met 64 jaar, met een gemiddelde van 40 jaar ( $\mathrm{SD}=\mathrm{I} 2$ jaar). De meeste respondenten hadden een hogere opleiding genoten $(45,2 \%)$; ruim een derde had een middelbare opleiding $(34,9 \%)$; een vijfde had een lagere opleiding ( $19,9 \%)$.

\subsection{Meetinstrumenten}

\section{Werkwaarden}

In de TNO Arbeidssituatie Survey 2002 is de respondenten gevraagd aan te geven op een vierpuntsschaal, variërend van niet erg belangrijk (I) tot heel erg belangrijk (4), hoe zij bepaalde aspecten van een baan in het algemeen waarderen. De vraag luidde: 'Kunt $\mathrm{u}$ aangeven welke aspecten u belangrijk en welke u minder belangrijk vindt bij het beoordelen van een baan in het algemeen?' De volgende zeven werkwaarden zijn met één item bevraagd: belang van zelfstandigheid, interessant werk, 
variatie, zekerheid, goede beloning, goede collega's en goede leiding.

\section{Werkkenmerken}

De volgende werkkenmerken zijn gemeten op vierpuntsschalen variërend van 'nooit' (I) tot 'altijd' (4).

Variatie in het werk is gemeten met vijf items. Een item dat variatie meet is 'Vereist uw baan dat $\mathrm{u}$ nieuwe dingen leert?' De variatieschaal heeft een interne consistentie (Cronbach's $\alpha$ ) van o.8I.

Autonomie in het werk is gemeten aan de hand van vijf items die een variant zijn op de 'decision lattitude'-vragen uit de Job Content Questionnaire (Karasek et al., 1998). De bewerkte en vertaalde JCQ-items zijn ontleend aan Goudswaard, Dhondt en Kraan (1998). Een voorbeelditem is 'Kunt u zelf beslissen hoe u uw werk uitvoert?' De autonomieschaal heeft een interne consistentie (Cronbach's $\alpha$ ) van o.86. Complexiteit in het werk is gemeten met vijf items die de kwalitatieve kant van werkdruk in beeld brengen, in dit geval het beslag dat het werk geestelijk legt op de werkende. De vragen zijn ontleend aan Houtman et al. (1995). Een voorbeelditem is 'Vereist uw werk intensief nadenken?' De interne consistentie (Cronbach's $\alpha$ ) van de complexiteitschaal is 0.82 .

Steun van de leidinggevende is gemeten met behulp van vier items die ontleend zijn aan de JCQ (Houtman, Goudswaard, Dhondt, Van der Grinten, Hildebrandt \& Kompier, 1995). Een voorbeelditem is 'Mijn chef besteedt aandacht aan wat ik zeg'. De interne consistentie (Cronbach's $\alpha$ ) van de schaal is o.84.

Steun van collega's is gemeten met vier items die ontleend zijn aan de JCQ (Houtman et al., 1995). Een voorbeelditem is 'Mijn collega's helpen het werk gedaan te krijgen'. De interne consistentie (Cronbach's $\alpha$ ) van de schaal is 0.78 .

Het volgende werkkenmerk heeft een $\mathrm{ja} / \mathrm{nee}$-schaal.

Baanzekerbeid is gemeten met drie items die ontleend zijn aan de vier items die Goudswaard et al. (1998) gebruiken voor het meten van baanzekerheid. We hebben ervoor gekozen om het item 'Zijn uw toekomstmogelijkheden in uw bedrijf gunstig?' niet mee te nemen omdat dit item laag correleert met de andere items en het de betrouwbaarheid van het construct baanzekerheid verlaagt. Een voorbeelditem van baanzekerheid is 'Loopt $\mathrm{u}$ risico om uw baan te verliezen?' De interne consistentie (Cronbach's $\alpha$ ) van de baanzekerheidschaal is o.84.

Maandinkomen ten slotte is gemeten door te vragen naar het nettomaandinkomen in klassen met een omvang van $€ 225$. Deze indeling in klassen van $€ 225$ is gekozen om een evenredige afspiegeling van het nettomaandinkomen in Nederland te verkrijgen.

\section{Uitkomstvariabele}

Arbeidstevredenheid is gemeten aan de hand van één item op een vijfpuntsschaal, variërend van 'zeer ontevreden' (I) tot 'zeer tevreden' (5). Het item luidt 'In welke mate bent u tevreden met uw werk?' Wanous, Reichers en Hudy (1997) hebben laten zien dat dergelijke maten voor arbeidstevredenheid een acceptabele betrouwbaarheid en validiteit hebben. 
Analyses

Met behulp van afzonderlijke hiërarchische multipele regressieanalyses is berekend hoe bepaalde werkwaarden, werkkenmerken en de fit tussen werkwaarde en werkkenmerk samenhangen met de arbeidstevredenheid. Als maat voor de fit is het product van het belang van de werkwaarde en het werkkenmerk genomen (Tinsley, 2000). Alvorens de productscore te berekenen zijn de onafhankelijke variabelen gecentreerd (Aiken \& West, 199I). De productscore is als variabele meegenomen in de regressieanalyse. In de eerste stap van de regressieanalyse zijn de demografische kenmerken geslacht, leeftijd en opleiding ingevoerd; in de tweede stap zijn de werkwaarde en het werkkenmerk ingevoerd; in de derde stap is de maat voor een goede fit ingevoerd.

\section{Resultaten}

Tabel 2 Gemiddelden, standaarddeviaties en correlaties van de variabelen met arbeidstevredenheid

\begin{tabular}{lccc}
\hline & M & $\begin{array}{c}\text { Standaard- } \\
\text { deviaties }\end{array}$ & $\begin{array}{c}\text { Correlatie met } \\
\text { arbeidstevredenheid }\end{array}$ \\
\hline Werkkenmerken & 2,90 & 0,65 &, $19\left(^{* *}\right)$ \\
\hline autonomie & 2,94 & 0,59 &, $23\left(^{* *}\right)$ \\
\hline variatie & 2,95 & 0,57 &, $1\left(^{* *}\right)$ \\
\hline complex werk & 3,21 & 0,49 &, $23\left(^{* *}\right)$ \\
\hline steun collega's & 2,80 & 0,63 &, $3\left(^{* *}\right)$ \\
\hline steun leidinggevende & 0,84 & 0,28 &, $08\left(^{* *}\right)$ \\
\hline baanzekerheid & 4,27 & 1,34 &, $07\left(^{* *}\right)$ \\
\hline maandinkomen & & &, $05\left(^{* *}\right)$ \\
\hline Werkwaarden & 3,47 & 0,61 &, $04\left(^{*}\right)$ \\
\hline belang interessant werk & 3,38 & 0,66 &,$- 07\left(^{* *}\right)$ \\
\hline belang zelfstandigheid & 3,41 & 0,65 &, 03 \\
\hline belang variatie & 3,33 & 0,65 &,- 02 \\
\hline belang goede beloning & 3,58 & 0,63 &,- 01 \\
\hline belang goede collega's & 3,47 & 0,71 & \\
\hline belang goede leiding & 3,29 & 0,76 & \\
\hline belang zekerheid & & & \\
\hline Tevredenheid & 3,91 & 0,79 & \\
\hline arbeidstevredenheid & & & \\
\hline
\end{tabular}

${ }^{*} p<0.05,{ }^{* *} p<0.01$

In tabel 2 worden de gemiddelden en standaarddeviaties van de werkwaarden en werkkenmerken gepresenteerd en de correlaties van de werkwaarden en werkkenmerken met arbeidstevredenheid. Autonomie in het werk, complex werk, variatie in het werk, baanzekerheid, inkomen en steun van leidinggevende en collega's hangen positief significant samen met arbeidstevredenheid. Ofwel, des te meer deze werk- 
kenmerken aanwezig zijn, des te hoger is de arbeidstevredenheid. Hiermee is hypothese I, die veronderstelde dat deze werkkenmerken positief samen zouden hangen met arbeidstevredenheid, ondersteund.

De intrinsieke werkwaarden belang van interessant werk, belang van zelfstandigheid en belang van variatie hangen positief significant samen met arbeidstevredenheid. Anders gezegd, hoe meer mensen hechten aan het hebben van interessant, zelfstandig en gevarieerd werk, des te tevredener zij zijn met hun werk. De extrinsieke werkwaarde belang van een goede beloning, daarentegen, hangt negatief samen met arbeidstevredenheid. Met andere woorden, naarmate mensen meer belang hechten aan een goede beloning, is de arbeidstevredenheid lager. De overige werkwaarden hangen niet significant samen met arbeidstevredenheid. Hypothese 2 is daarmee ondersteund.

In tabel 3 worden zeven afzonderlijke regressies van een werkwaarde, een werkkenmerk en de fit tussen werkwaarde en werkkenmerk op de arbeidstevredenheid gepresenteerd. Er is steeds gekozen voor een combinatie van een werkkenmerk dat zo dicht mogelijk aanligt tegen het werkkenmerk waar belang aan wordt gehecht. De tabel geeft een overzicht van de ongestandaardiseerde B's en de p-waarden van de werkwaarden, de werkkenmerken en de interactie tussen de werkwaarde en het werkkenmerk. De p-waarde van de incrementele F-toets geeft aan of het invoeren van de interactieterm significant bijdraagt aan de verklaarde variantie van arbeidstevredenheid (Jaccard, Turrisi \& Wan, 1990).

Volgens hypothese 3 verwachtten we dat een fit tussen werkwaarde en werkkenmerk positief bijdraagt aan arbeidstevredenheid. Voor mensen die hechten aan het hebben van interessant werk, neemt de tevredenheid meer toe naarmate zij meer complex werk hebben dan voor mensen die weinig waarde hechten aan het hebben van complex werk $(\mathrm{p}<$.05). Echter bij weinig complex werk zijn mensen die sterk hechten aan interessant werk alsnog tevredener dan mensen die weinig hechten aan interessant werk. Dit resultaat staat grafisch weergegeven in figuur I. Een goede fit tussen de werkwaarde variatie in het werk en het werkkenmerk variatie leidt tot meer arbeidstevredenheid $(\mathrm{p}<$.oor). Figuur 2 laat zien dat de arbeidstevredenheid meer toeneemt voor mensen die een groot belang hechten aan gevarieerd werk, naarmate de variatie in het werk toeneemt. Bij weinig variatie in het werk zijn de mensen die weinig waarde aan variatie hechten tevredener met het werk dan mensen die sterk hechten aan het hebben van gevarieerd werk. Figuur 3 geeft weer dat voor werkenden die hechten aan zekerheid, de tevredenheid meer toeneemt naarmate zij meer baanzekerheid ervaren dan voor werkenden die minder sterk hechten aan zekerheid. Wanneer er weinig zekerheid is, ervaren mensen die minder sterk hechten aan zekerheid meer arbeidstevredenheid dan mensen die veel waarde hechten aan zekerheid $(\mathrm{p}<.01)$. De andere vier combinaties van werkwaarde en werkkenmerk leiden niet tot meer arbeidstevredenheid. Een goede fit tussen de werkwaarde zelfstandigheid in het werk en het werkkenmerk autonomie draagt niet bij aan de arbeidstevredenheid. Belang hechten aan goede collega's en een goede leiding ging niet gepaard met meer arbeidstevredenheid naarmate er meer steun van collega's en leidinggevende was. Ten slotte zien we dat mensen die veel waarde hechten aan inkomen niet tevredener zijn naarmate zij meer verdienen ${ }^{1}$. De verwachting dat een goede fit tussen werkwaarde en werkkenmerk tot meer arbeidstevredenheid leidt, wordt dus gedeeltelijk bevestigd. 
Tabel 3 Ongestandaardiseerde coëfficiënten voor werkwaarden, voorkomen van werkkenmerken en de interactie tussen werkwaarde en voorkomen werkkenmerk, $\mathrm{R}^{2}$ en incrementele F-toets

\begin{tabular}{|c|c|c|c|c|c|}
\hline & & B & $\mathbf{R}^{2}$ & Verandering $\mathbf{F}$ & $\begin{array}{l}\text { Significantie } \\
\text { verandering } \\
\text { F (p-waarde) }\end{array}$ \\
\hline \multirow[t]{2}{*}{ 1) Model 1} & Belang interessant werk &, $06^{* *}$ & 0,014 & $F(2,3901)=20,74$ & ,00 \\
\hline & Complex werk & $12^{* * *}$ & & & \\
\hline \multirow[t]{3}{*}{ Model 2} & Belang interessant werk &, $07 * *$ & 0,015 & $F(1,3900)=4,61$ &, 03 \\
\hline & Complex werk & $12 * * *$ & & & \\
\hline & $\begin{array}{l}\text { Complex werk } \mathrm{x} \text { belang } \\
\text { interessant werk }\end{array}$ & $07^{*}$ & & & \\
\hline \multirow[t]{2}{*}{ 2) Model 1} & Belang zelfstandigheid in werk & .00 & 0,031 & $F(2,3917)=55,06$ &, 00 \\
\hline & Autonomie in werk & $23^{* * *}$ & & & \\
\hline \multirow[t]{3}{*}{ Model 2} & Belang zelfstandigheid in werk & 01 & 0,031 & $F(1,3916)=2,26$ & n.s. \\
\hline & Autonomie in werk & $23^{* * *}$ & & & \\
\hline & Autonomie $\mathrm{x}$ belang zelfstandigheid & .05 & & & \\
\hline \multirow[t]{2}{*}{ 3) Model 1} & Belang variatie in werk &,- 02 & 0,053 & $F(2,3918)=103,72$ &, 00 \\
\hline & Variatie in werk & $32 * * *$ & & & \\
\hline \multirow[t]{3}{*}{ Model 2} & Belang variatie in werk &,- 00 & 0,061 & $F(1,3917)=31,97$ & .00 \\
\hline & Variatie in werk & $32 * * *$ & & & \\
\hline & Variatie $\mathrm{x}$ belang variatie &, $17^{* * *}$ & & & \\
\hline \multirow[t]{2}{*}{ 4) Model 1} & Belang goede collega's & ,00 & 0,058 & $F(2,3729)=108,49$ & .00 \\
\hline & Steun collega's &, $38 * * *$ & & & \\
\hline \multirow[t]{3}{*}{ Model 2} & Belang goede collega's & .01 & 0,058 & $F(1,3728)=1,26$ & n.s. \\
\hline & Steun collega's & $38 * * *$ & & & \\
\hline & $\begin{array}{l}\text { Steun collega's } x \text { belang } \\
\text { goede collega's }\end{array}$ & .04 & & & \\
\hline \multirow[t]{2}{*}{ 5) Model 1} & Belang goede leiding &,$- 04^{*}$ & 0,133 & $F(2,3337)=251,81$ & .00 \\
\hline & Steun leidinggevende & $45^{* * *}$ & & & \\
\hline \multirow[t]{3}{*}{ Model 2} & Belang goede leiding &,$- 04 *$ & 0,133 & $F(1,3336)=1,06$ & n.s. \\
\hline & Steun leidinggevende & $45^{* * *}$ & & & \\
\hline & $\begin{array}{l}\text { Steun leidinggevende } \mathrm{x} \\
\text { belang goede leiding }\end{array}$ & .03 & & & \\
\hline \multirow[t]{2}{*}{ 6) Model 1} & Belang zekerheid & .00 & 0,051 & $F(2,3896)=101,33$ &, 00 \\
\hline & Baanzekerheid & $.61 * * *$ & & & \\
\hline \multirow[t]{3}{*}{ Model 2} & Belang zekerheid & ,00 & 0,054 & $F(1,3895)=10,43$ &, 00 \\
\hline & Baanzekerheid &, $59 * * *$ & & & \\
\hline & Baanzekerheid $\mathrm{x}$ belang zekerheid &, $19 * *$ & & & \\
\hline \multirow[t]{2}{*}{ 7) Model 1} & Belang beloning &,$- 08^{* * *}$ & 0,012 & $F(2,3681)=14,92$ &, 00 \\
\hline & Inkomen &, $05^{* * *}$ & & & \\
\hline \multirow[t]{3}{*}{ Model 2} & Belang beloning &,$- 07 * * *$ & 0,013 & $F(1,3680)=3,43$ & n.s. \\
\hline & Inkomen &, $05 * * *$ & & & \\
\hline & Inkomen $\mathrm{x}$ belang inkomen & .03 & & & \\
\hline
\end{tabular}




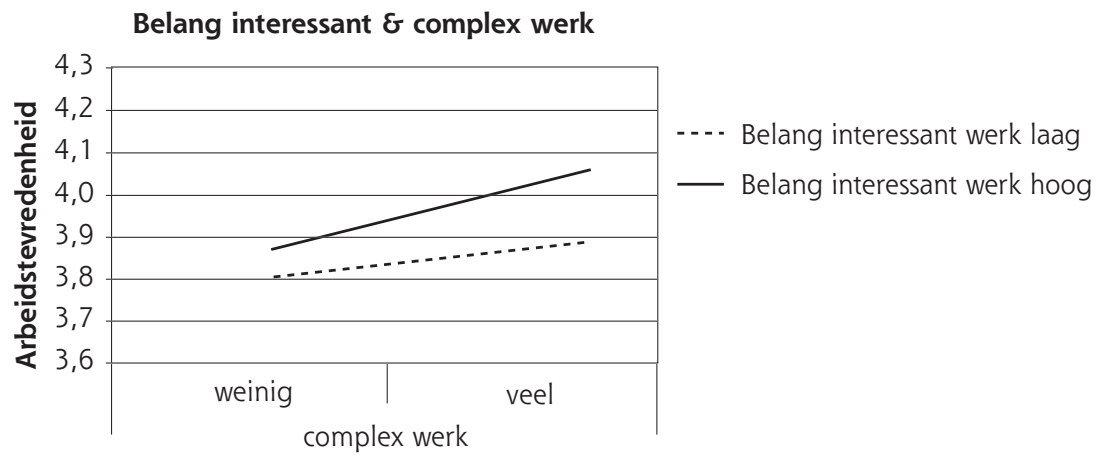

Figuur 1 Interactie-effect van belang van variatie in het werk en variatie in het werk ( $n=3907$ )

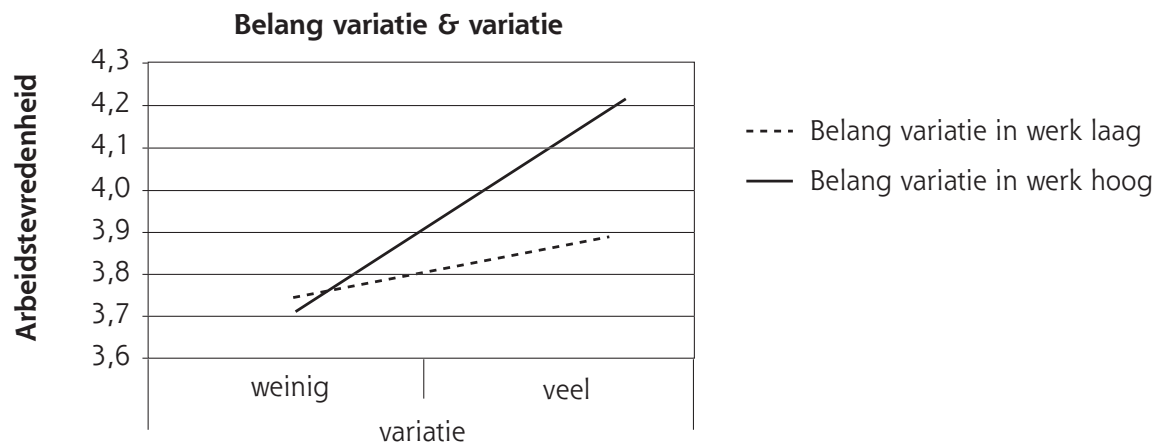

Figuur 2 Interactie-effect van belang van interessant werk en variatie in het werk $(n=3924)$

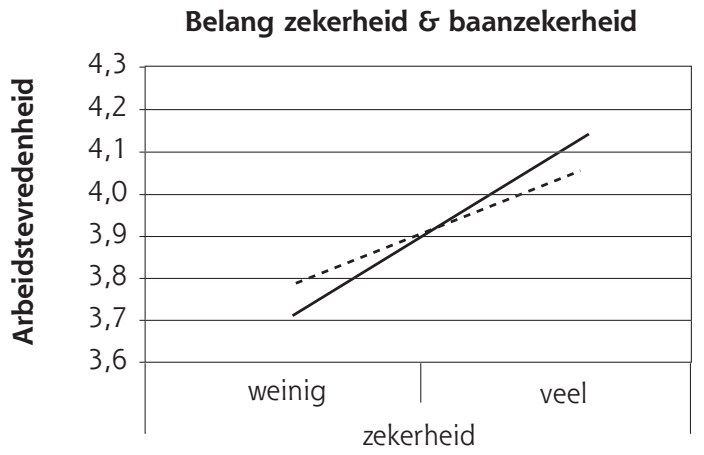

-..- Belang zekerheid laag

— Belang zekerheid hoog

Figuur 3 Interactie-effect van belang van zekerheid en baanzekerheid ( $\mathrm{n}=3897$ ) 


\section{Discussie}

Het Vitaminemodel van Warr (1987) gaat uit van het idee dat een sterke aanwezigheid van een werkkenmerk niet altijd tot meer arbeidstevredenheid leidt. Wanneer er sprake is van een (te) grote mate van aanwezigheid van het werkkenmerk, neemt de tevredenheid niet langer toe - in het geval van een CE-werkkenmerk - of neemt zelfs af - in het geval van een AD-werkkenmerk. Daarnaast stelt het Vitaminemodel dat een passende combinatie van persoonskenmerk en werkkenmerk kan bijdragen aan de arbeidstevredenheid. In dit onderzoek volgden we het idee dat een werkkenmerk niet altijd tot meer arbeidstevredenheid leidt. We veronderstelden dat een werkkenmerk vooral tot meer arbeidstevredenheid leidt, wanneer er waarde wordt gehecht aan het werkkenmerk. De hypothese dat een goede fit gepaard gaat met een grotere arbeidstevredenheid kan gedeeltelijk bevestigd worden. Voor mensen die belang hechten aan het hebben van interessant werk, is het hebben van complex werk belangrijker voor de arbeidstevredenheid dan voor mensen die weinig hechten aan interessant werk. Een goede fit tussen belang hechten aan variatie in het werk en het werkkenmerk variatie in het werk draagt bij aan de arbeidstevredenheid. Ten slotte is voor werkenden die een groot belang hechten aan zekerheid in het werk baanzekerheid belangrijker voor de arbeidstevredenheid dan voor werkenden die in mindere mate hechten aan zekerheid.

De aanleiding van dit onderzoek was dat sommige auteurs steun hebben gevonden voor de veronderstelling dat een goede fit tussen werkwaarden en werkkenmerken bijdraagt aan arbeidstevredenheid (Boer et al., 2003) en anderen niet of nauwelijks (Achterberg et al., 2003; Zurriaga et al., 2000). Een goede fit tussen werkwaarde en werkkenmerk droeg in dit onderzoek niet altijd bij aan meer arbeidstevredenheid. $\mathrm{Zo}_{\mathrm{o}}$ is het opvallend dat wij niet hebben gevonden dat een goede fit tussen belang hechten aan zelfstandigheid en het hebben van autonomie in het werk bijdraagt aan meer arbeidstevredenheid, terwijl Achterberg et al. (2003) en Boer et al. (2003) wel vonden dat een goede fit tussen behoefte aan autonomie en autonomie in het werk bijdroeg aan meer tevredenheid. Een mogelijke verklaring hiervoor is dat het meten van de werkwaarden aan de hand van één item, met onbekende betrouwbaarheid en validiteit, de kans op het aantonen van een interactie-effect verkleint (McClelland \& Judd, r993). Het is dan ook raadzaam om in de toekomst gebruik te maken van gevalideerde en betrouwbare schalen om de werkwaarden in kaart te brengen. Niettemin hebben we in dit onderzoek in drie van de zeven gevallen (ofwel 43\%) kunnen aantonen dat de werkwaarde het effect van het werkkenmerk op de arbeidstevredenheid modereert.

Werkenden die hechten aan goede collega's of een goede leiding zijn tevredener met hun werk naarmate zij meer steun van hun collega's of leidinggevende krijgen, maar dit geldt ook voor werkenden die weinig waarde hechten aan goede collega's of goede leiding. Wellicht is steun van de leidinggevende en collega's zo belangrijk dat het er weinig toe doet hoeveel waarde iemand aan deze werkkenmerken hecht. Een andere verklaring voor het uitblijven van een positief effect van een goede fit, is dat er meer dan steun nodig is om een 'goede' collega te zijn. Of, in het geval van de leidinggevende, zien de werknemers 'goede leiding' breder dan alleen steun van de direct leidinggevende. Het lijkt erop dat in deze combinaties de werkwaarde niet voldoende aansloot bij het werkkenmerk. Ook de werkwaarde belang hechten aan 
een goede beloning ligt te veraf van het werkkenmerk maandinkomen. Hoewel gevraagd is naar het eigen inkomen en niet naar het gezinsinkomen, is het mogelijk dat het inkomen niet alleen uit inkomen uit werk bestond, maar ook uit inkomen uit andere bronnen. De werkwaarde en het werkkenmerk moeten dicht bij elkaar liggen om een effect van een goede fit te vinden. Zo zien we dat de fit tussen belang van variatie in het werk en de variatie in het werk meer bijdraagt aan arbeidstevredenheid dan belang van interessant werk en complex werk. In het geval van de werkwaarde belang hechten aan een goede beloning, kunnen we ons afvragen wat een goede beloning is. Dit is uiteraard een subjectief begrip. Een goede beloning is wat de werkende zelf een goede beloning vindt. We zien dan ook dat werkenden die een groot belang aan een goede beloning hechten, tevredener zijn naarmate zij meer van mening zijn dat hun loon voldoende is voor het werk dat zij doen.

Hoewel dit onderzoek enige steun heeft gevonden voor het idee dat een goede fit tussen werkwaarden en werkkenmerken bijdraagt aan een grotere arbeidstevredenheid, hebben we gezien dat de werkkenmerken een relatief groot aandeel van de arbeidstevredenheid verklaren. Met Achterberg et al. (2003) concluderen wij dat werkkenmerken op zich belangrijk zijn voor een goede arbeidstevredenheid. Echter, net als Boer et al. (2003) voegen we daar aan toe dat - naast de werkkenmerken een goede fit tussen werkwaarden en werkkenmerken eveneens bijdraagt aan een grotere arbeidstevredenheid.

\section{Methodologische aspecten}

De grote en gevarieerde steekproef in dit onderzoek geeft enerzijds vertrouwen in de resultaten. Waar Boer et al. (2003) en Achterberg et al. (2003) een tamelijk homogene steekproef hebben - voornamelijk respondenten van hetzelfde geslacht en werkzaam in verwante sectoren - is de steekproef in dit onderzoek zeer heterogeen. Anderzijds zijn kleine verbanden in een grote steekproef al gauw significant. Zo is bijvoorbeeld de correlatie tussen maandinkomen en arbeidstevredenheid relatief laag $(\mathrm{r}=.08)$, maar toch nog significant $(\mathrm{p}<. . \mathrm{oI})$. Wat betreft interactie-effecten is dit echter niet het geval. In veldonderzoeken zijn interactie-effecten namelijk moeilijk aan te tonen en verklaren doorgaans slechts weinig variantie (McClelland \& Judd, I993). Dit komt onder meer doordat er voor het ontdekken van interactie-effecten voldoende waarnemingen nodig zijn op de vier combinaties van extremen op de beide predictoren (hoog belang - veel werkkenmerk, hoog belang - weinig werkkenmerk, laag belang - veel werkkenmerk, laag belang - weinig werkkenmerk). Doordat in veldonderzoek de meeste mensen ongeveer gemiddeld scoren op de verschillende variabelen, zijn dergelijke combinaties van extreme waarnemingen relatief zeldzaam, waardoor er grote steekproeven nodig zijn om interactie-effecten te ontdekken. In dit onderzoek is de steekproef groot. Desondanks zijn er weinig werknemers die extreem laag scoren op de werkwaarden in combinatie met een extreem lage of hoge score op het werkkenmerk. Ook de combinatie van een hoge score op de werkwaarde en een lage score op het werkkenmerk komt weinig voor. Als we desalniettemin vanwege de grote steekproef het significantieniveau zouden verhogen van .05 tot .oor, zijn er alsnog nog twee van de zeven interacties (ofwel 29\%) significant.

De mogelijke verklaringen voor het uitblijven van een effect van een goede fit tussen werkwaarden en werkkenmerken, laten een aantal methodologische tekortkomingen 
in dit onderzoek zien. De werkwaarden zijn slechts met één item gemeten en de combinaties van werkwaarden en werkkenmerken waren niet altijd optimaal. Bovendien is in het onderzoek alleen gebruikgemaakt van zelfrapportage, wat het moeilijker maakt om een interactie aan te tonen, aangezien zelfrapportage zelden extreme waarden oplevert (Warr, 1994). Ten slotte is het zo dat dit onderzoek gebruik heeft gemaakt van cross-sectionele data, wat impliceert dat de gevonden relaties niet als causaal mogen worden geïnterpreteerd. Naast de effecten van de werkwaarden, werkkenmerken en een fit tussen werkwaarden en werkkenmerken op de arbeidstevredenheid is het mogelijk dat de arbeidstevredenheid de beoordeling van de werkwaarden en de werkkenmerken beïnvloedt. Longitudinaal onderzoek laat echter zien dat het pad van werkkenmerken richting arbeidstevredenheid (causaal) dominanter is dan andersom (Ter Doest \& De Jonge, in druk; De Jonge et al., 200I).

\section{Toepassingen}

In de praktijk betekenen de resultaten dat werkgevers die streven naar tevreden personeel zich ervan bewust moeten zijn dat niet alleen het werk zelf bepalend is voor de mate van arbeidstevredenheid, maar ook of het werk past bij wat een werknemer waardeert in een baan. Een werkkenmerk dat voor de ene werknemer cruciaal is voor de arbeidstevredenheid, is dat voor een andere werknemer, met andere werkwaarden, niet. Maatwerk zou waar mogelijk nagestreefd moeten worden. Dit inzicht komt van pas bij het selecteren en plaatsen van personeel. Een voorbeeld hiervan kan zijn om bij de selectie van personeel niet alleen te letten op capaciteiten, maar ook op de werkwaarden van de sollicitant. Passen deze bij de kenmerken van de functie? Ook bij het inzetten van p\&o-instrumenten zoals taakroulatie of taakuitbreiding zou een personeelsfunctionaris zich af moeten vragen of dit bij de werknemer past. Het uitbreiden of rouleren van taken dient met name aangeboden te worden aan mensen die belang hechten aan interessant en gevarieerd werk. Werknemers doen er op hun beurt goed aan om bij het accepteren van een nieuwe baan zich van tevoren af te vragen in welke mate het nieuwe werk aansluit bij wat zij belangrijk vinden in een baan. Zij moeten daarvoor eerst helder hebben wat zij belangrijk vinden in een baan. In het sollicitatiegesprek, via toekomstige collega's of op andere wijze kunnen zij vervolgens gericht informatie verzamelen over de werkkenmerken van de nieuwe functie en beoordelen in welke mate de werkkenmerken overeenkomen met wat zij waarderen in het werk.

\section{Noot}

1 We hebben ter exploratie berekend of een goede fit tussen de werkwaarde belang van een goede beloning en het werkkenmerk voldoende loon/salaris ontvangen voor het werk dat men doet, bijdraagt aan de arbeidstevredenheid. Dit is inderdaad het geval $(\mathrm{p}<.01)$.

\section{Literatuur}

Achterberg, P., Houtman, D. \& Jetten, B. (2003). Arbeidstevredenheid: een aanpassingsfenomeen? Tijdschrift voor Arbeidsvraagstukken, I9, 214-227.

Agho, A.O., Mueller, C.W. \& Price, J.L. (1993). Determinants of employee job satisfaction: An empirical test of a causal model. Human Relations, 46, 1007-I027. 
Aiken, L.S. \& West, S.G. (I99I). Multiple Regression: Testing and Interpreting Interactions. Newbury Park, CA: Sage Publications.

Boer, F.M., Jonge, J. de \& Hamers, J.P.H. (2003). De relatie van werkkenmerken en bijpassende persoonskenmerken met psychisch welbevinden. Gedrag E̋ Organisatie, 16, 22I-236.

Doest, L. ter \& Jonge, J. de (in druk). Testing causal models of job characteristics and employee well-being: A replication study using cross-lagged structural equation modelling. Journal of Occupational and Organizational Psychology.

Elizur, D. (1996). Work values and commitment. International Journal of Manpower, I7, 25-30.

Goudswaard, A., Dhondt, S. \& Kraan, K. (1998). Flexibilisering en Arbeid in de Informatiemaatschappij; werknemersvragenlijst, bestemd voor werknemers van bedrijven die deelnemen aan het $S Z W$-Werkgeverspanel 1998 . Hoofddorp: TNO Arbeid.

Harpaz, I. (2002). Expressing a wish to continue or stop working as related to the meaning of work. European Journal of Work and Organizational Psychology, II, I77-I98.

Hoof, J.J. van, Bruin, P.E.M., Schoemaker, M.J.R. \& Vroom, A. (2002). Werk(en) moet wel leuk zijn. Den Haag: Koninklijke Van Gorcum/Stichting Management Studies.

Houtman, I., Goudswaard, A., Dhondt, S., Grinten, M. van der, Hildebrandt, V. \& Kompier, M. (1995). Evaluatie van de monitorstudie naar stress en lichamelijke belasting. Den Haag: VUGA.

Jaccard, J.J., Turrisi, R. \& Wan, C.K. (1990). Interaction effects in multiple regression. Newbury Park, CA: Sage.

Jeurissen, T. \& Nyklíček, I. (200I). Testing the Vitamin Model of job stress in Dutch health care workers. Work and Stress, I5, 254-264.

Jonge, J. de, Dormann, C., Janssen, P.P.M., Dollard, M.F., Landeweerd, J.A. \& Nijhuis, F.J.N. (200I). Testing reciprocal relationships between job characteristics and psychological well-being: A cross-lagged structural equation model. Journal of Occupational and Organizational Psychology, 74, 29-46.

Jonge, J. de \& Schaufeli, W.B. (1998). Job characteristics and employee well-being: a test of Warr's Vitamin Model in health care workers using structural equation modelling. Journal of Organizational Behavior, 19, 387-407.

Karasek, R., Brisson, C., Kawakami, N., Houtman, I., Bongers, P. \& Amick, B. (1998). The Job Content Questionnaire (JCQ): an instrument for internationally comparative assessments of psychosocial job characteristics. Journal of occupational health psychology, $3,322-355$.

Knoop, R. (1994). Work values and job satisfaction. Journal of Psychology, 683-69o.

McClelland, G.H. \& Judd, C.M. (I993). Statistical difficulties of detecting interactions and moderator effects. Psychological Bulletin, II4, 376-390.

Nadler, A. (199I). Help seeking behavior: Psychological costs and instrumental benefits. In M.S. Clark (Ed.), Review of personality and social psychology (I2 ed., pp. 290-312). New York: Sage.

Norris, P. (2003). Is there still a public service ethos? Work values, experience, and job satisfaction among government workers. In J.D. Donahue \& J.S. Nye (Eds.), For the People: Can We Fix Public Service? Washington D.C.: Brookings institution press.

Peeters, M.C.W. \& Le Blanc, P.M. (200I). Towards a match between job demands and sources of social support: A study among oncology care providers. European Journal of Work and Organizational Psychology, $10,53^{-} 72$.

Pool, S. (1997). The relationship of job satisfaction with substitutes of leadership, leadership behavior, and work motivation. Journal of Psychology, I3I, 27I-283.

Smulders, P.G.W., Andries, F. \& Otten, F. (200I). Hoe denken Nederlanders over hun werk? Opzet, kwaliteit en eerste resultaten van de TNO Arbeidssituatie Survey. Hoofddorp: TNO Arbeid.

Smulders, P.G. \& Houtman, I.L.D. (2004). Oorzaken van werkdruk: een onderbelicht thema. Tijdschrift voor Arbeidsvraagstukken, 20, 90-107.

Snir, R. \& Harpaz, I. (2002). Work-leisure relations: leisure orientation and the meaning of work. Journal of Leisure Research, 34, 178-203. 
Tinsley, H.E.A. (2000). The congruence myth: an analysis of the efficacy of the personenvironment fit model. Journal of Vocational Behavior, 56, I47-179.

Velde, M.E.G. van der, Feij, J.A. \& Emmerik, H. van (1998). Change in work values and norms among young Dutch adults: ageing or societal trends? International Journal of Behavioral Development, 22, 55-76.

Wanous, J.P., Reichers, A.E. \& Hudy, M.J. (1997). Overall Job Satisfaction: How Good Are Single-Item Measures? Journal of Applied Psychology, 82, 247-252.

Warr, P. (1994). A conceptual framework for the study of work and mental health. Work and Stress, 8, 84-97.

Warr, P.B. (1987). Work, Unemployment, and Mental Health. Oxford: Clarendon Press.

Ybema, J.F. \& Smulders, P.G.W. (2004). Centraliteit van werk en het belang van werkkenmerken. In I.L.D.Houtman, P.G.W. Smulders \& D.J. Klein Hesselink (Eds.), Trends in arbeid 2004 (pp. 95-II3). Amsterdam: PlantijnCasparie.

Yperen, N.W. van \& Jong, J.I. de (I997). Is een tevreden werknemer ook een productieve werknemer? Gedrag E' Organisatie, 69-77.

Zurriaga, R., Ramos, J., Gonzalez-Roma, V., Espejo, B. \& Zornoza, A. (200o). Effects of job characteristics on job satisfaction, organizational commitment and absenteeism in health care organizations / Efecto de las características del puesto de trabajo sobre la satisfacción el compromiso y el absentismo en organizaciones sanitarias. Revista de Psicología Social Aplicada, ro, 85-98.

\section{Summary}

\section{Job satisfaction: result of job characteristics, work values or both?}

Marije Evers, Jan Fekke Ybema \& Peter Smulders, Gedrag \& Organisatie, Volume 19, Maart 2006, nr. 1, pp. 37-52

This paper explores how job characteristics and work values influence job satisfaction in a sample of the Dutch working population ( $N=4009)$. In accordance with the Vitamin Model, we expected that the presence of a job characteristic would only lead to (increased) job satisfaction under certain circumstances. In this study, we hypothesised that a job characteristic would lead to increased job satisfaction especially in cases of a good fit between work value and job characteristic. Some studies showed that such a good fit contributed to job satisfaction, while other studies found little or no evidence. Our research showed that the hypothesis held true in three out of seven cases. In other words, a good fit between work value and job characteristic sometimes resulted in higher levels of job satisfaction. Our paper therefore concludes that not only are work characteristics important for job satisfaction, but also the extent to which work values and work characteristics coincide.

Key words: work values, job characteristics, job satisfaction 